University of Nebraska - Lincoln

DigitalCommons@University of Nebraska - Lincoln

8-2008

\title{
Do Tax-Exempt Yields Adjust Slowly to Substantial Changes in
} Taxable Yields?

Donna Dudney

University of Nebraska-Lincoln, ddudney1@unl.edu

John Geppert

University of Nebraska-Lincoln, jgeppert1@unl.edu

Follow this and additional works at: https://digitalcommons.unl.edu/financefacpub

Part of the Finance and Financial Management Commons

Dudney, Donna and Geppert, John, "Do Tax-Exempt Yields Adjust Slowly to Substantial Changes in Taxable Yields?" (2008). Finance Department Faculty Publications. 2.

https://digitalcommons.unl.edu/financefacpub/2

This Article is brought to you for free and open access by the Finance Department at DigitalCommons@University of Nebraska - Lincoln. It has been accepted for inclusion in Finance Department Faculty Publications by an authorized administrator of DigitalCommons@University of Nebraska - Lincoln. 
Published in The Journal of Futures Markets 28:8 (2008), pp. 763-789; doi 10.1002/fut.20332 Copyright (C) 2008 Wiley Periodicals, Inc. Used by permission.

http://www.interscience.wiley.com

Submitted November 2005; accepted September 2007.

\title{
Do Tax-Exempt Yields Adjust Slowly to Substantial Changes in Taxable Yields?
}

\author{
Donna Dudney and John Geppert \\ College of Business Administration, University of Nebraska-Lincoln, \\ Lincoln, Nebraska, USA \\ Corresponding author - D. Dudney, Interim Assistant Dean, University of \\ Nebraska-Lincoln, College of Business Administration, P.O. Box 880405, \\ Lincoln, Nebraska 68588-0405. tel 402 472-5695, fax 402 472-5140, email \\ ddudney1@unl.edu
}

\begin{abstract}
This paper examines the profitability of two futures trading strategies: a municipal bond futures contract strategy and a spread strategy consisting of a municipal bond futures contract and a Treasury bond futures contract. Both strategies are designed to exploit a slow municipal yield adjustment following changes in Treasury yields. We find economically significant profits to both strategies. Average holding period returns per trade for both strategies tend to increase with the magnitude of the Treasury yield change. Profit distributions associated with various Treasury yield change thresholds tend to be positively skewed, and median profits are significantly lower than average profits. The profitability results are consistent with slow municipal yield adjustments.
\end{abstract}

\section{Introduction}

The relationship between taxable and tax-exempt yields has been an extensively researched topic in finance. Theory suggests that tax-exempt and taxable yields for similar risk bonds should differ by an amount equal to the tax burden. However, numerous studies document anomalous behaviors in the shape of the tax-exempt yield curve relative to the taxable yield curve. Several 
researchers found that the marginal tax rate implied by the spread between tax-exempt and taxable yields decreases with maturity (see Ang, Peterson, \& Peterson, 1985; Green, 1993; Kryzanowski, Xu, \& Zhang, 1995; Skelton, 1983). In addition, the municipal yield curve almost always has a positive slope (even when the taxable yield curve is inverted), and generally has a steeper slope than the taxable yield curve.

Explanations of these anomalies have generally centered on market imperfections such as restrictions on short-selling, high transactions costs associated with arbitrage by individuals due to bid/ask spreads, market segmentation in the municipal market, and portfolio construction techniques that minimize the tax burden on taxable bonds. ${ }^{1}$ Although many of these imperfections limit profitable trading in the cash markets, profitable strategies are possible in the futures markets using the municipal bond futures contract.

Previous studies have examined the relationship between the tax-exempt and taxable yield curves at a particular point in time. As an alternative, this study looks at the relationship between tax-exempt and taxable yields following changes in taxable yields. Specifically, this study examines whether taxexempt yields adjust quickly to changes in taxable yields by investigating the profitability of futures trading strategies designed to exploit a slow municipal yield adjustment. If taxable yields decline, municipal yields will be higher than aftertax corporate yields. In an efficient market, municipal yields should quickly adjust downward as investors buy the relatively more attractive municipals. If taxable yields decline (prices rise), but tax-exempt yields adjust with a lag, investors may be able to profit by buying the undervalued tax-exempt bonds and selling them when yields adjust downward and prices rise.

The municipal marketplace is frequently characterized by thin trading, so a profitable strategy that exploits a slow municipal yield adjustment may be difficult to implement in the cash market. However, trades to capitalize on a slow adjustment can be quickly and easily executed in the futures market at low cost. The success of two futures trading strategies is examined. The first strategy is a short (long) position in the municipal futures contract following Treasury yield increases (decreases). The second strategy is a spread strategy consisting of a short (long) position in the municipal futures contract and a long (short) position in the Treasury bond futures contract following Treasury bond yield increases (decreases).

1. Green (1993) argued that investors can shield coupon income from taxation by constructing portfolios of non-par bonds that generate offsetting losses or investment interest expense. If these techniques are employed, the effective marginal tax rate on these taxable portfolios may be low even though the portfolio has pretax cash flows that are similar to those of portfolios consisting of taxable par bonds. However, as discussed in McDonald (2006), most of these portfolio construction techniques are no longer allowed under current tax law. 
Profitable results from both trading strategies were found, suggesting that tax-exempt yields may adjust slowly to increases and decreases in taxable yields. Significant profits generally exist when the trading strategies are implemented for five-day holding periods following a change in taxable yields. Per-trade profits from the strategies tend to increase with the magnitude of the change in taxable yields. If the strategies are executed following larger changes in taxable yields, substantial average profits exist. For example, average five-day gross profits per trade from implementing the municipal bond futures strategy following Treasury yield increases of eight basis points or more are $\$ 289$ per $\$ 100,000$ position. Assuming transactions costs of $\$ 35$ per contract, and a spread margin requirement of $\$ 1,013$, this translates to a fiveday holding period return per trade of $25.03 \%$. The distribution of holding period profits is generally highly skewed, as evidenced by the median holding period return of $8.89 \%$. The results provide evidence of exploitable profit opportunities in the tax-exempt futures market. However, due to the risk associated with the trading strategy, professional arbitrage activities may be impeded because the volatility of the profit stream may make the strategy difficult for professional money managers to justify to their investors. Shleifer and Vishny (1997) noted that even if a position is ultimately profitable, if it generates variable outcomes, investors may infer that the manager is not competent and refuse to provide him with more capital.

The article is organized as follows: the first section briefly discusses the relevant literature and the second section discusses the methodology utilized in this study. The results of the futures market trading strategy are discussed in the third section, followed by summary and conclusions in the last section.

\section{Literature Review}

Given perfect, frictionless markets, the after-tax yields on tax-exempt and taxable bonds with identical risk characteristics, maturities, and callability features should be equal. This relationship can be described by the following equation:

$$
Y_{\text {exempt }}=Y_{\text {taxable }}(1-T)
$$

where $Y_{\text {exempt }}$ is the yield on a tax-exempt bond selling at par, $Y_{\text {taxable }}$ is before-tax yield on a taxable bond selling at par, $T$ is the marginal tax rate of the marginal investor.

Frequently, Equation (1) is used to solve for the implied marginal tax rate $(T)$ that equates the after-tax return on taxable bonds with the tax-exempt 
yield. This implied marginal tax rate is then compared with actual marginal tax rates to determine whether tax-exempt bond yields are reasonable given prevailing tax rates.

Previous research indicates that implied marginal tax rates for longer maturity bonds are consistently substantially below the top marginal tax rate, implying that municipal bonds are mispriced relative to taxable bonds (research generally compares AAA municipal bonds with equivalent maturity Treasury bonds). This apparent anomaly, dubbed the muni puzzle, has been attributed to several factors. Litzenberger and Rolfo (1984) pointed to market imperfections caused by restrictions on short-selling and high transactions costs in the municipal marketplace. Chalmers (2006) explored the hypothesis that municipal bonds expose investors to higher levels of systematic consumption risk than comparable taxable bonds, but found little empirical support for this explanation of the muni puzzle. Wu, Wang, and Zhang (2006) showed that municipal bond yields are strongly affected by liquidity and default risk, and found that after controlling for these risks, the implied marginal tax rates are very close to the statutory tax rates of high-income individuals and corporations. McCue and Stevens (1992), and Skelton (1983) argued that yield differentials are consistent with market segmentation in the municipal market. Before 1986, banks were allowed to deduct the interest on funds used to purchase tax-exempts. Banks concentrate holdings of tax-exempts in shorter maturities, so the pricing of short-term tax-exempts is dictated by the marginal tax rate of commercial banks, whereas the longterm market is determined by the marginal tax rates of individuals and nonbank corporations. However, the "cost of carry" deduction was largely eliminated in 1986, and is now only allowed on bonds of small municipal issuers (defined as municipalities issuing less than \$10 million in a calendar year). Although the IRS rules disallow deductions for interest used to purchase tax-exempts, a safe-harbor rule allows corporations and individuals to engage in a limited amount of tax arbitrage by allowing holdings of municipal bonds in an amount equal to $2 \%$ of assets. Erickson, Goolsbee, and Maydew (2003) found that only a tiny fraction of corporations appear to be engaged in any significant amount of tax arbitrage; the vast majority have municipal holdings far less than the safe-harbor level.

With the introduction of the original municipal bond futures contract in June of 1985, and a revised contract in October of 2002, investors can more easily exploit mispricing between taxable and tax-exempt bonds by purchasing a futures contract on the underpriced security and selling a futures contract on the overpriced security. Transactions costs for futures trades are very low, and the municipal bond futures contract can be shorted even though it is difficult to short municipal bonds themselves. 
Several studies have examined the pricing of the municipal bond futures contract and the spread between the municipal bond futures contract and Treasury futures (called the MOB spread). Arak, Fischer, Goodman, and Daryanani (1987) developed a model of the theoretical range for the MOB spread. They found that compared with the theoretical arbitrage bounds, the original municipal futures contract was mispriced in its early months, but traded within the arbitrage bounds thereafter. Using a cash and carry pricing model for the municipal bond index futures contract that incorporates the impact of changing index composition, Hamilton, Hein, and Koch (1994) found similar results; the first five nearby municipal bond futures contracts had substantial pricing errors, but the 22 subsequent contracts between September 1985-December 1990 were generally priced consistently according to the theoretical model. In contrast, Heaton (1988) developed theoretical arbitrage bounds for the MOB spread and showed that while the tax rate does not affect the Treasury futures price, the arbitrage-preventing futures price for the municipal futures contract is not independent of the investor's tax rate. This means that the prevailing futures price prevents arbitrage only for investors in a single tax bracket (i.e. that tax bracket implied by the prices of the municipal and Treasury futures contracts). Arbitrage opportunities would still exist for investors in higher or lower tax brackets.

Hung and Zhang (1995) examined the relationship between the original municipal bond futures contract and the Bond Buyer 40 Index used as the cash instrument for the original contract. They found that the Bond Buyer 40 Index and the futures contract prices are nonstationary but cointegrated. Consistent with results from other futures markets, price changes in the municipal bond futures contract lead price changes in the Bond Buyer 40 Index, supporting the idea that the futures market leads the cash market in incorporating new information.

Harris and Piwowar (2006) provided a comprehensive analysis of the trading costs in spot municipal bond markets. They developed an innovative econometric method to estimate the trading costs for retail and institutional size trades in the secondary market. Six issue characteristics affect the trading costs: trading volume, credit quality, complexity of bond features, issue size, time since issuance, and time until maturity. Interestingly, they find that costs decrease with trading size, but not with trading frequency. The effective bid-ask spreads in the municipal bond secondary market average $2 \%$ for trades under $\$ 20,000$ and $1 \%$ for trades over $\$ 200,000$. These costs are substantially higher than comparably sized equity trades. For comparison, they calculated that a $2 \%$ spread on 500 shares of equity at $\$ 40$ per share would amount to an $\$ 0.80$ bid-ask spread, far greater than what is typically seen in equity markets. In addition to the relatively high trading 
costs in the municipal bond spot market, the market is reflected by relatively low trading volume. For example in the Harris and Piwowar sample, $30 \%$ of the bonds traded less than ten times during a one-year period. The low trading volume and high trading cost limit the ability to exploit slow adjustments in the spot municipal bond market.

In summary, prior research suggests that profit opportunities may be present in the municipal market, but unique institutional features of this market may limit the ability of investors to exploit these opportunities, particularly in the cash market. Previous studies compare the level of taxable yields to the level of tax-exempt yields. Regardless of the correct model of establishing initial relative pricing relationships, prices should quickly return to the initial relationship following interest rate changes. To the knowledge of the authors, this study is the first to examine the profitability of a trading strategy designed to exploit slow adjustments in municipal yields.

\section{Methodology}

Two simple futures trading strategies were devised, which were designed to generate profits if municipal yields adjust with a lag to changes in taxable yields. Using the futures market to exploit any lag in the tax-exempt yield adjustment has several advantages over the use of individual tax-exempt and taxable bonds. First, individual tax-exempt issues trade over-the-counter through a dealer network. The dealer market is characterized by high bid-ask spreads and thin trading, resulting in high transactions costs and potential liquidity issues. The futures contract is an exchange-traded contract with significant daily volume. Second, as noted by Litzenberger (1984) and Hamilton et al. (1994), it is difficult to short individual Treasury and municipal bonds. Generally, bonds that are shorted must be borrowed through reverse repurchase agreements. Under this arrangement, the short-seller uses the proceeds of the bond sale as collateral. Trading in the repurchase market is very thin, thus making it difficult to implement short transactions. In contrast, the futures market has no institutional barriers to short-selling.

Futures positions can be established with a much smaller initial outlay than investments in the bonds themselves. The initial margin requirement for one municipal bond futures contract is $\$ 1,013$, whereas the initial margin requirement for one T-Bond futures contract is $\$ 1,553$. Even lower margins are allowed on intramarket spread positions; the margin on an MOB spread position (one municipal bond futures contract and one Treasury bond futures contract) is $\$ 743$.

Municipal bond futures contracts were first introduced in 1985, when the Chicago Board of Trade introduced a contract based on the Bond Buyer 40 In- 
dex, an index of high-grade long-term municipal bonds. ${ }^{2}$ The original contract was replaced on October 25, 2002, by a new contract based on the notional price of a synthetic ten-year municipal note, with the price based on an index composed of 100-250 municipal bonds. ${ }^{3}$

According to the Bond Market Association Municipal Bond Futures Task Force (2000), the original municipal bond futures contract had pricing discrepancies. The original index was based on the Bond Buyer 40, which was priced twice daily using the average of quotes from five brokers. Many of the bonds in the index were closely held by a limited number of investors who did not trade their positions, so the index quotes represented indicative bid prices not prices on actual trades, and problems with liquidity occurred. The Task Force noted that prices of bonds in the index were often bid-up or bid-down during the last minutes on expiration day, even though no transactions occurred at those prices in the cash market. Because of these pricing discrepancies, the original municipal bond futures contract was not included in the analysis.

\section{Description of the Futures Trading Strategies}

The profits from a futures strategy that utilizes only the municipal futures contract are first examined. If municipal bonds respond with a lag to a Treasury yield decrease, profits will be generated by a long position in the municipal bond futures contract following decreases in the Treasury yield. As both the Treasury and the municipal bond futures prices would be expected to increase with a yield decrease, if the Treasury price responds first, the municipal bond futures contract will initially be undervalued relative to the Treasury futures contract, but will gradually adjust upward. A long strategy in

2. The original municipal bond futures contract was based on the Bond Buyer 40 Index (BB40), with the unit of trading equal to $\$ 1,000$ times the BB40 Index. The BB40 index is composed of 40 longterm, fixed coupon, actively traded bonds rated A- or better by S\&P or A or better by Moody's Investors Service. Bonds included in the index must have an issue size of at least $\$ 50$ million and a remaining maturity of at least 19 years (and a first call date between 7 and 16 years). The Treasury bond futures contract is based on a $\$ 100,000$ face value Treasury bond with a maturity (or first call, if callable) of at least 15 years from the first day of the delivery month. The invoice price equals the futures settlement price times a conversion factor plus accrued interest, where the conversion factor is the price of the delivered bond ( $\$ 1$ par value) assuming a yield of $6 \%$. Similar to other indexbased futures contracts, the muni bond futures contract uses cash settlement.

3. The new municipal bond futures contract introduced in October of 2002 is based on the notional price of a synthetic ten-year municipal note with a par value of $\$ 100,000$, and a fixed, semiannual coupon of 5\%. The futures price is based on an index comprising100-250 municipal bonds. Eligible bonds must have a minimum term size of $\$ 50$ million and must be a component traunche of an issue with a total size of at least $\$ 200$ million. Bonds must be initially rated AAA by both Moody's and Standard \& Poor's (although the rating may fall to AA or A after inclusion in the index). Index bonds must have a remaining maturity between 10 and 40 years, at least 7 years to the first call date, an original issue price of at least 90; and fixed semiannual coupon payments between 3 and $9 \%$. The Index bonds are priced once daily by FT Interactive Data Corporation, an independent pricing service. The contract uses cash settlement. 
the municipal bond futures contract will exploit this adjustment pattern. Similarly, slow municipal yield adjustments following Treasury yield increases could be exploited by shorting the municipal bond futures contract.

The second trading strategy implements a spread position in the futures market using the municipal bond futures contract and the Treasury futures contract. The municipal over bond spread (MOB spread) is defined as a long position in one municipal bond contract and a short position in one Treasury futures contract. If municipal yields adjust with a lag, a long (short) position in the MOB spread following yield decreases (increases) should be profitable. Superior performance of the municipal futures strategy compared with the spread strategy indicates that the primary yield response is to municipal yields following taxable yield changes. If both the municipal contract and the Treasury contract show adjustment following Treasury yield changes, the spread strategy will dominate the municipal only strategy.

Because the municipal bond futures contract is based on a ten-year note, changes in Treasury yields are calculated using the constant maturity ten-year Treasury Note yield, as reported in Federal Reserve Economic Data (FRED). Closing prices for both the Treasury and municipal bond futures contracts were obtained from the Continuously Linked Commodity Contracts database published by Pinnacle Data.

The success of the futures trading strategies was separately examined following increases and decreases in Treasury yields. As noted by Hamilton et al. (1994), the cost and risk of shorting cash municipals is greater than the cost and risk from buying municipals, resulting in asymmetric cash-and-carry arbitrage bounds on the municipal futures price. Therefore, the profitability of a short futures strategy implemented following yield increases may differ from the profitability of a long futures strategy implemented following Treasury yield decreases.

To determine whether trading strategy profits are sensitive to the size of a taxable yield change, profits from a $\$ 100,000$ position in each of the futures trading strategies are calculated using daily Treasury yield change thresholds of one to ten basis points, for the time period from October 25, 2002, to May 31, 2004.

To prevent confounding effects of overlapping event dates, the futures strategies are based on nonoverlapping event dates. If a second large yield change occurs before the end of the holding period for a position taken due to an initial large yield change, the investor is assumed not to implement the futures trading strategy on the second large change. Although not reported here, gross profits were also calculated assuming overlapping event dates. ${ }^{4}$

4. The gross profits from the overlapping analysis generally tend to be smaller. With the exception of the spread strategy following yield decreases, all strategies remain profitable under the overlapping methodology. 
A strategy of shorting municipal bonds will generate profits if, during the sample period as a whole, interest rates trend upward. Similarly, a strategy of buying municipal bonds will generate profits if interest rates trend downward during the sample period. To ensure that the results are due to the timing of the strategies and not just overall trends in interest rates, the gross profit from a strategy of consistently shorting or buying the municipal bond futures contract or MOB spread for all nonoverlapping holding periods of three or five days was also calculated. These results, not reported here, show much lower (and generally negative) profits when compared to the timing strategies.

\section{Results Of Futures Trading Strategies}

\section{Descriptive Statistics and Analysis}

Table I gives the distribution of daily yield changes for the ten-year Treasury bond for the period from October 25, 2002, to May 5, 2004. The number of yield increases and decreases is approximately equal over the period and the distribution is roughly symmetrical. Figure 1 shows the time series behavior of the ten-year Treasury bond yield and the municipal bond futures contract price, whereas Figure 2 compares the time series behavior of the Treasury bond futures contract price and the municipal bond futures contract price. There was substantial variation in Treasury bond yields over the sample period, with yields ranging from a low of $3.13 \%$ on June 13,2003 , to a high of $4.85 \%$ on May 13, 2004. The largest daily increase in Treasury bond yields over the sample period was 24 basis points on April 2, 2004, whereas the largest daily yield decrease was a 21 basis point decrease on November 7, 2002.

Table I. Distribution of Ten-Year Constant Maturity Treasury Yields October 25, 2002, to May 5, 2004

\begin{tabular}{lccrc}
\hline Percentile & Level & Change & Count & For the Change \\
\hline 100 & 4.85 & 0.24 & 2 & Greater than or equal to percentile \\
90 & 4.472 & 0.08 & 44 & \\
80 & 4.35 & 0.05 & 81 & \\
70 & 4.24 & 0.03 & 127 & \\
60 & 4.16 & 0.01 & 163 & \\
50 & 4.07 & 0 & 204 & \\
40 & 4.01 & -0.02 & 165 & \\
30 & 3.95 & -0.03 & 134 & \\
20 & 3.836 & -0.05 & 72 & \\
10 & 3.63 & -0.08 & 44 & \\
0 & 3.13 & -0.21 & 1 & \\
Average & 4.07 & 0.00 & & \\
Std. dev. & 0.335 & 0.0671 & & \\
Number & 399 & 398 & & \\
\hline
\end{tabular}



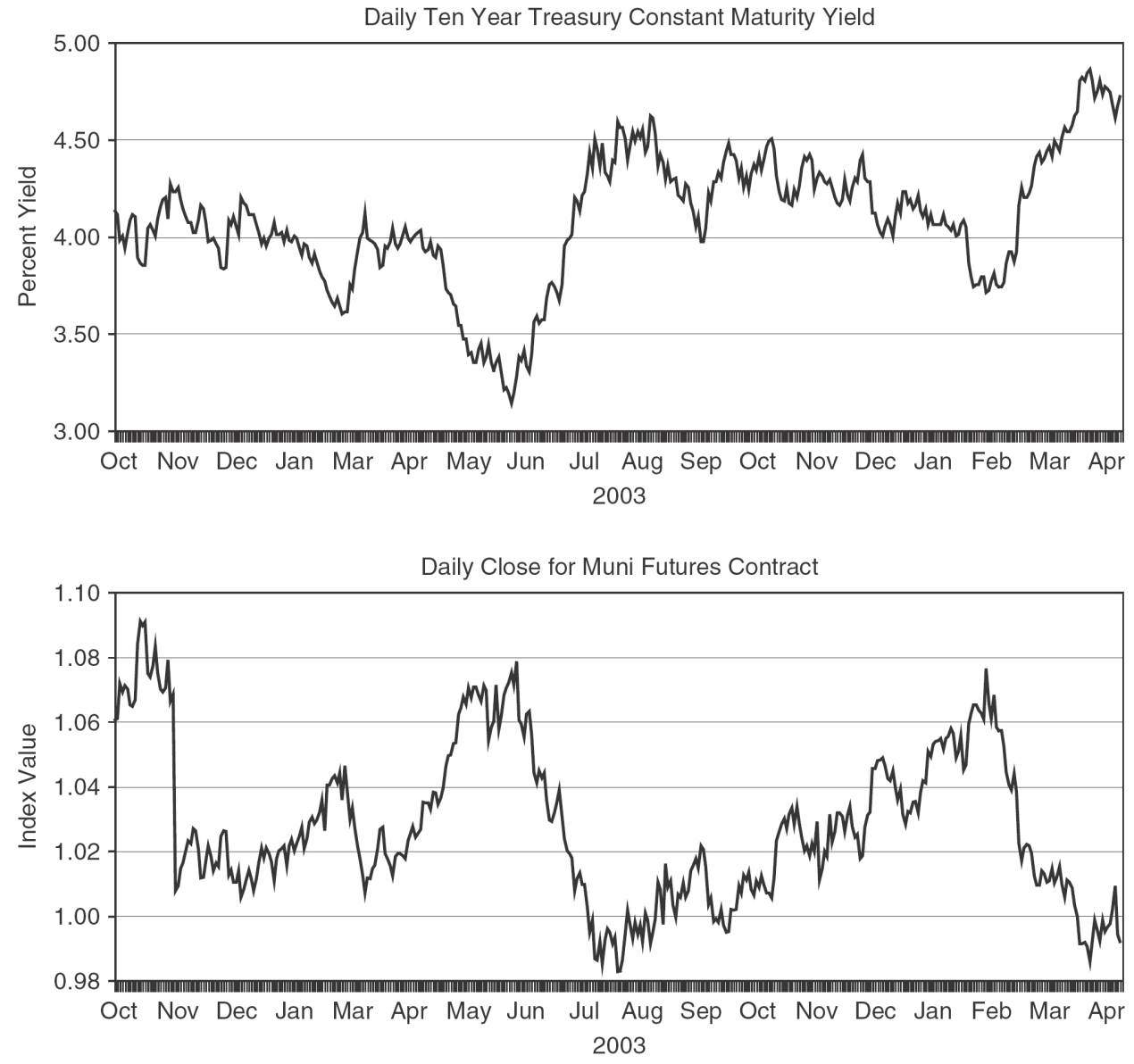

Figure 1. Historical ten-year treasury yields and municipal bond futures contract prices.

The average daily volume in the municipal bond contract for the sample period is 373 trades per day with average open interest of 2,656 contracts. Although this is a thinly traded market, the median daily volume does increase (almost monotonically from 265 to 425) with the size of the changes in the Treasury yield. This provides further evidence that traders in the municipal market do react to changes in the Treasury yield.

Results of Municipal Bond Futures Contract Strategy for Treasury Yield Increases

Table II gives the distribution of gross per-trade profits on a $\$ 100,000$ contract for three-day (Panel A) and five-day (Panel B) holding periods for the 

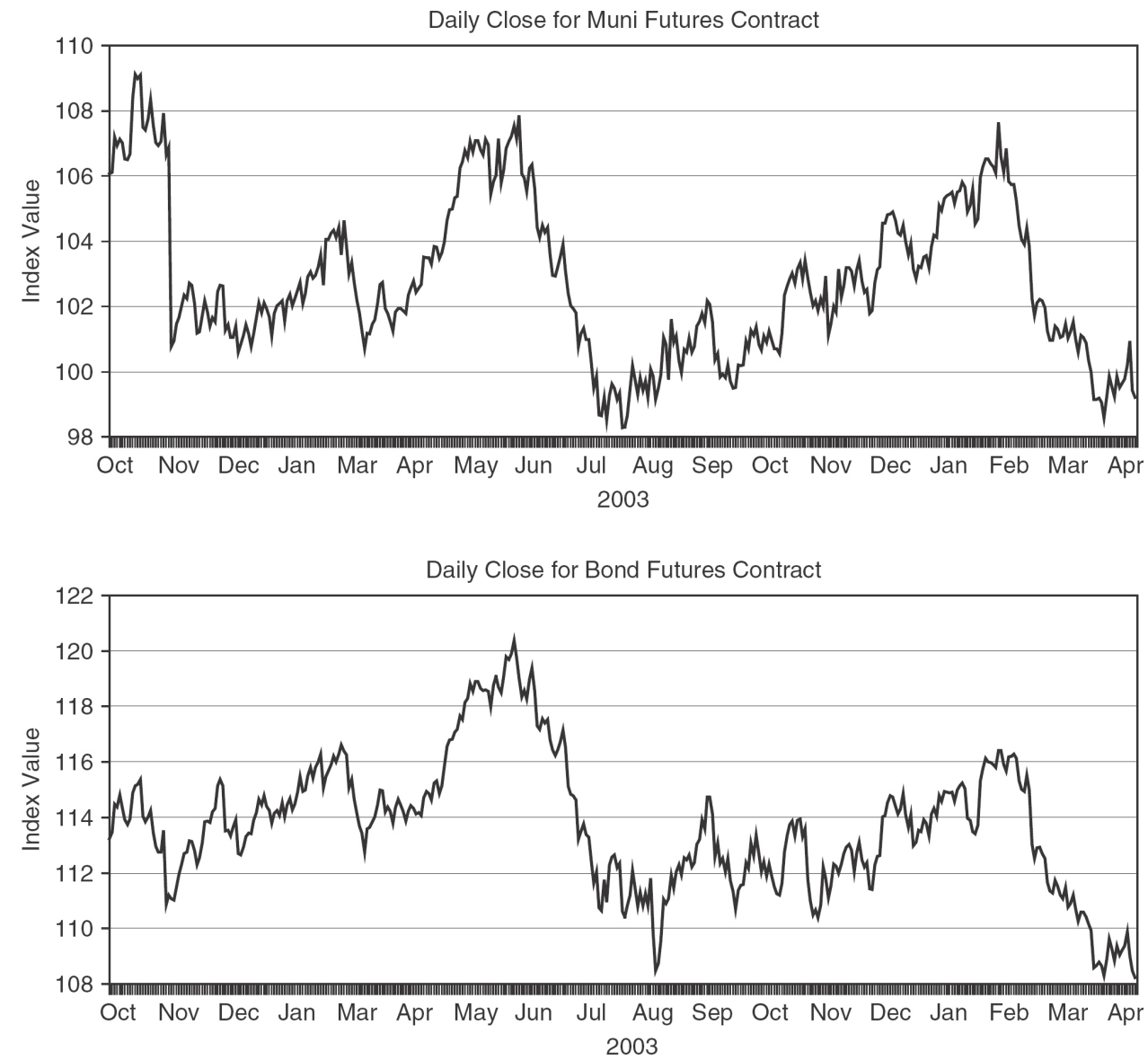

Figure 2. Historical prices for municipal bond futures contract and treasury bond futures contract.

municipal futures trading strategy implemented following Treasury yield increases. The distribution of profits is shown separately for Treasury yield increase thresholds of one to ten basis points.

Average three-day per-trade profits from the municipal futures trading strategy are consistently positive for all Treasury yield change thresholds, and range from a low of $\$ 77$ when the strategy is implemented following one basis point or more changes in Treasury yields (88 instances) to a high of $\$ 284$ when futures positions are taken following eight basis point or more changes in Treasury yields (35 instances). Holding period per-trade profits generally increase as the Treasury yield change threshold increases, with a marked increase in profitability for yield change increases of five basis points or more. 


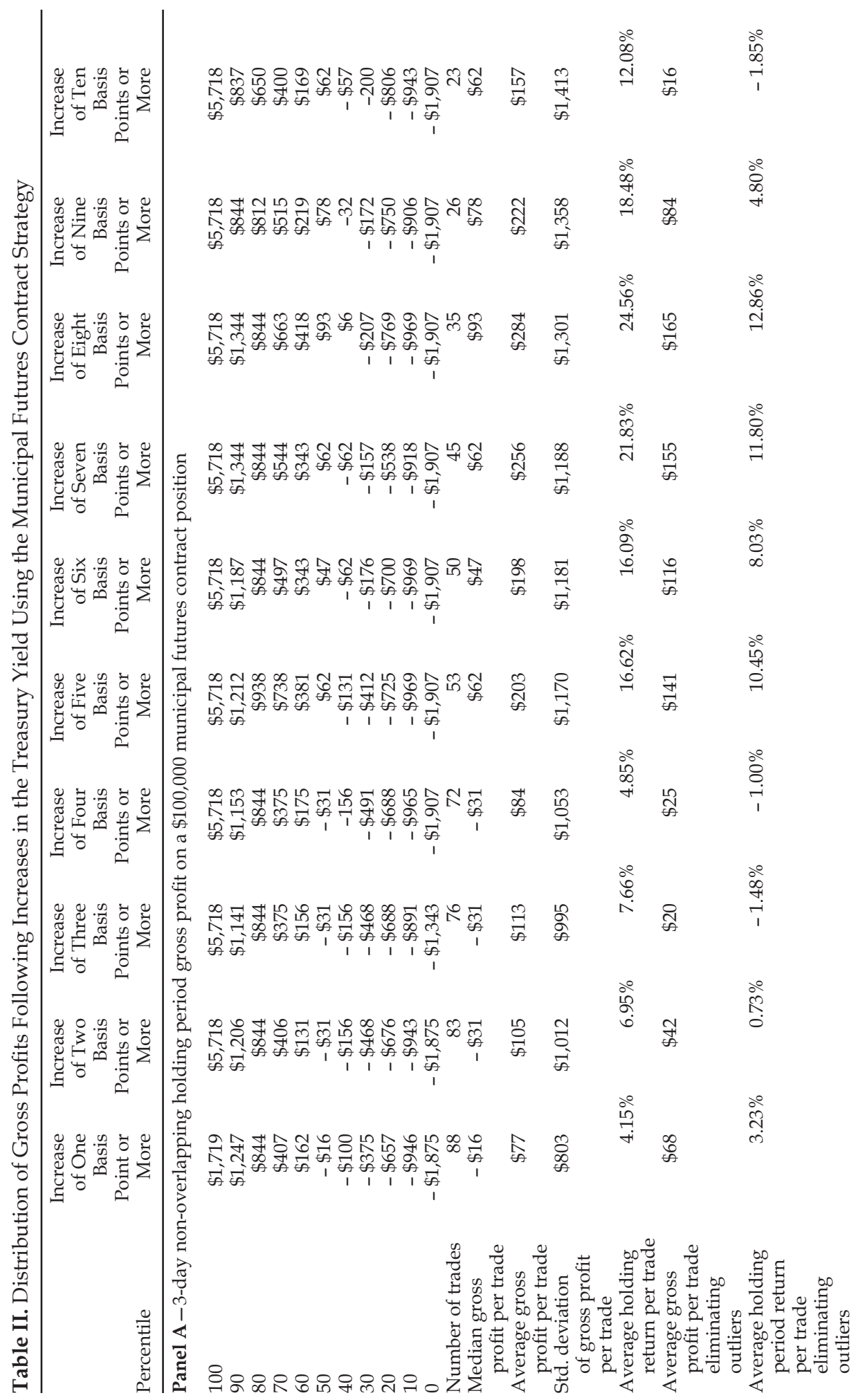




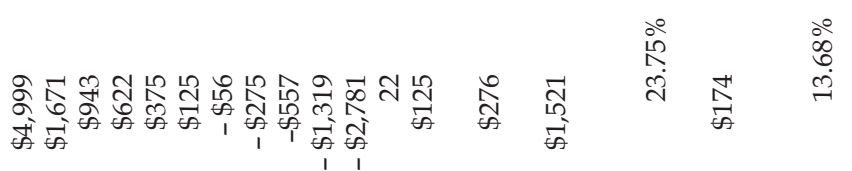

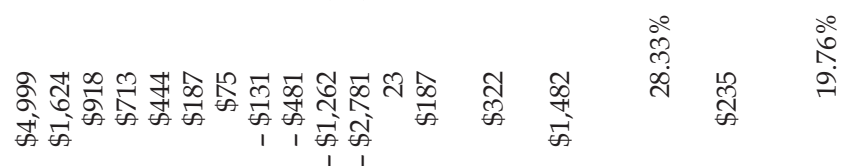

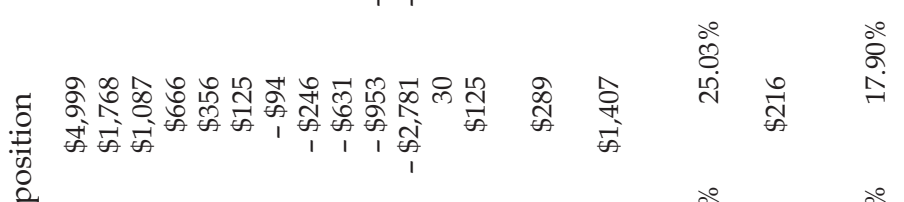

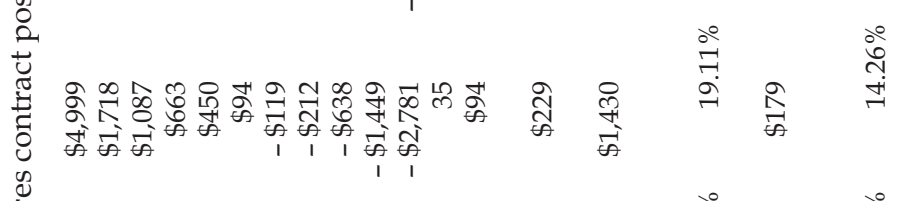

苞

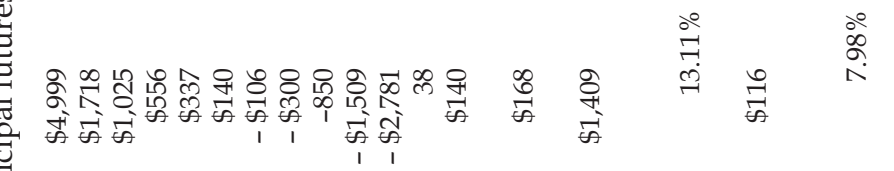

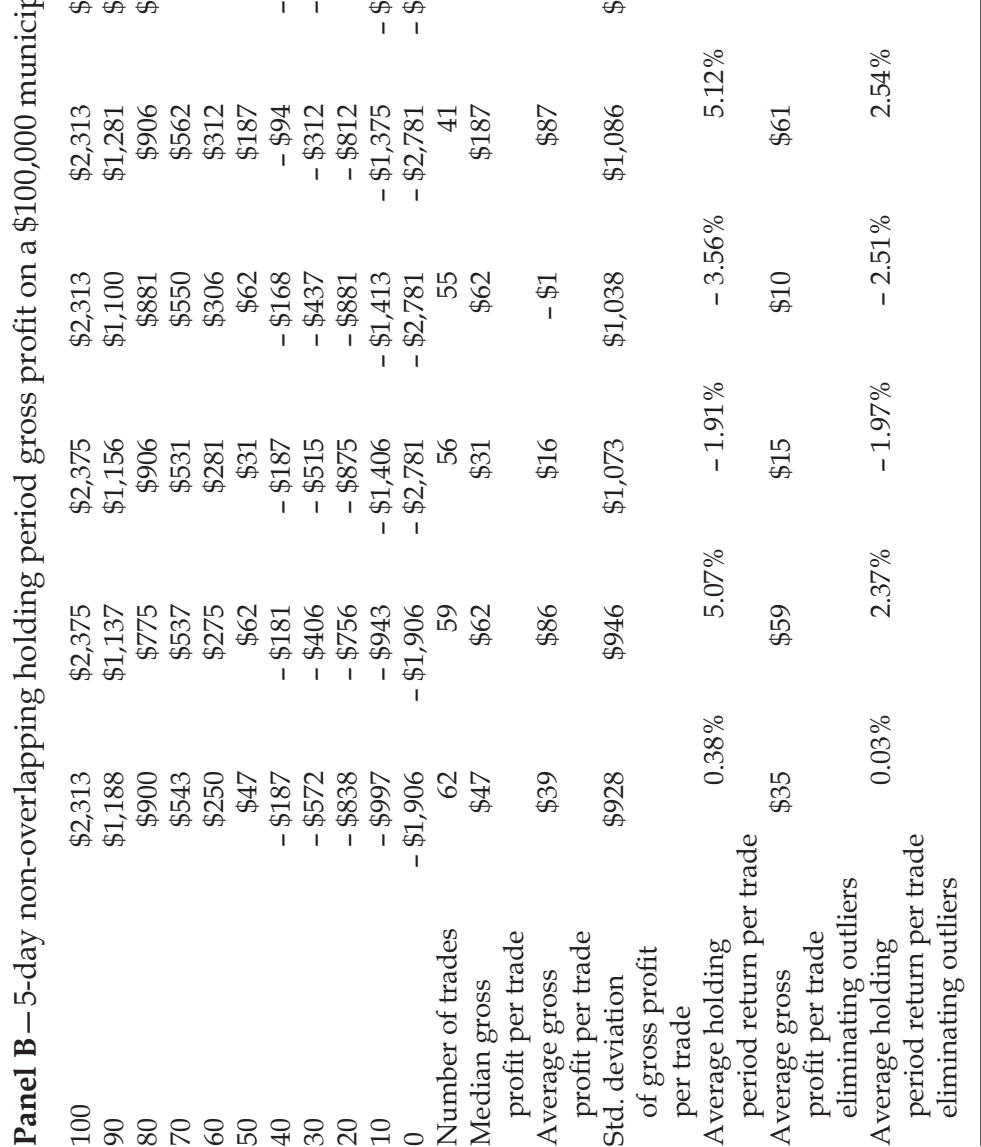

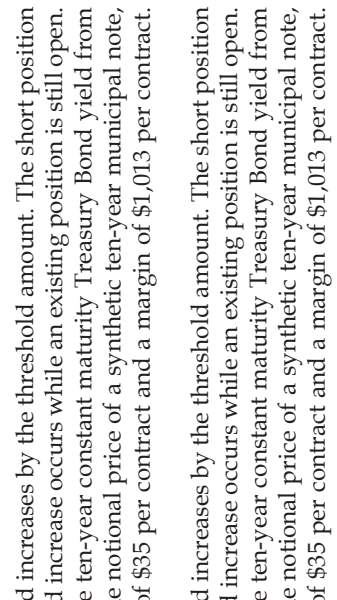

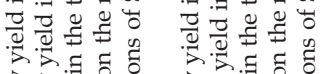

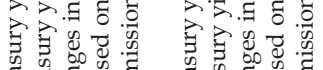

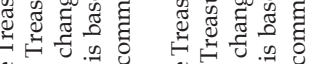

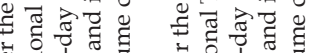

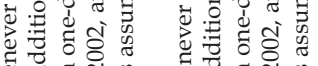

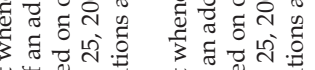

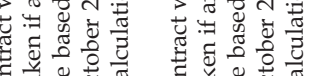

50.

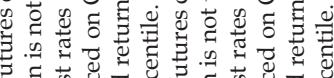

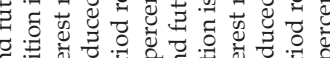

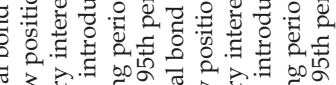

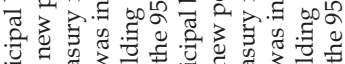

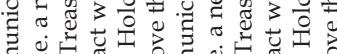

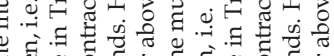

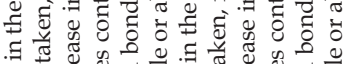

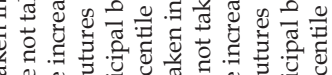

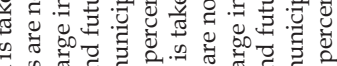

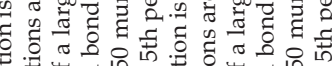

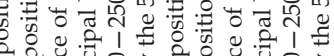

等

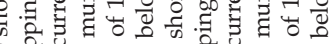

8 :

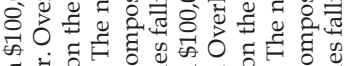

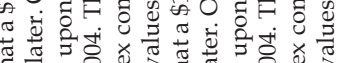

$=0$

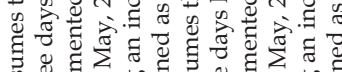

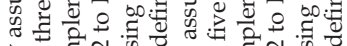

كo

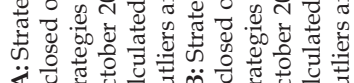

齐. 
Although per-trade holding period profits tend to increase with increases in the Treasury yield change threshold, the total dollar profits at lower yield change thresholds are still economically significant given the larger number of trades possible at these lower yield thresholds.

At Treasury yield increase thresholds below five basis points, median 3-day profits per trade are negative. Median profits are positive at yield change thresholds of five basis points or more; however, median profits are significantly less than average profits, indicating skewness in the profit distributions.

The three-day profits associated with the municipal futures trading strategy are particularly significant given the low cost of undertaking this strategy. The initial margin for the municipal bond future contract is $\$ 1,013$, and transactions costs (including the bid-ask spread) range from $\$ 28$ to $\$ 41$ per contract. ${ }^{5}$ Based on transactions costs of $\$ 35$, the net three-day holding period returns to the trading strategy if it is implemented when the Treasury yield increases by five or more basis points ranges from $12.08 \%$ (ten basis point Treasury yield increase) to $24.56 \%$ (eight basis point Treasury yield increase).

Profits from the municipal futures trading strategy implemented following larger increases in Treasury yields persist for at least five days, as given in Panel B of Table II. Five-day per-trade profits associated with Treasury yield increases of five basis points or less tend to be small or negative. However, for Treasury yield increases of six basis points or more, five-day profits persist. These profits are only slightly smaller than the three-day profits for six and seven basis point Treasury yield increases (13.11 and $19.11 \%$, respectively, for five-day, versus 16.09 and $21.83 \%$ for three-day), and are actually larger than the three-day profits for eight, nine, and ten basis point Treasury yield increases $(25.03,28.33$, and $23.75 \%$, respectively, for five-day, versus $24.56,18.48$, and $12.08 \%$ for three-day). Median five-day profits are consistently positive at all Treasury yield increase thresholds, but increase dramatically at Treasury yield increases of five basis points or more.

\section{Results of MOB Spread Futures Contract Strategy for Treasury Yield Increases}

The three- and five-day per-trade profits for the MOB spread trading strategy are shown on Table III, Panels A and B, respectively. Transactions

5. The source of the initial margin requirement is the Chicago Board of Trade 10-Year Municipal Note Index Futures Reference Guide, whereas the transactions costs come from an article entitled "CBOT Celebrates 25th Anniversary of Its Interest Rate Complex," published online by the Chicago Board of Trade. 
costs for the MOB spread strategy are slightly higher than for the municipal futures strategy as two contracts are purchased (resulting in transactions costs of $\$ 70$ per position). However, the spread margin of $\$ 743$ is significantly less than the margin of $\$ 1,013$ required for the municipal futures contract.

The three-day holding period MOB spread strategy generates small or negative returns when implemented following Treasury yield increases of less than eight basis points. However, the spread strategy generates higher returns than the municipal futures strategy for Treasury yield change thresholds of nine and ten basis points (31.72 and $38.50 \%$ for the spread strategy for nine and ten basis points, respectively, compared with 18.48 and $12.08 \%$ for the municipal futures strategy). Surprisingly, results for the five-day holding period spread strategy are significantly better than the results for the threeday holding period (see Panel B). Although the five-day holding period returns remain negative at Treasury yield increases of less than six basis points, returns for Treasury yield change thresholds of six basis points or more range from $25.11 \%$ (for the seven basis point threshold) to $52.56 \%$ (for the ten basis point threshold). Three-day holding period median profits for the MOB strategy are negative or very small for Treasury yield increase thresholds below eight basis points, but are \$141 and \$252 for Treasury yield change thresholds of nine and ten basis points, respectively. Median per-trade profits for the five-day holding period are positive at Treasury yield increase thresholds above five basis points, and are substantial at Treasury yield change thresholds above seven basis points.

\section{Results of Municipal Bond Futures Contract Strategy for Treasury Yield Decreases}

Table IV gives the per-trade profits associated with the municipal bond futures contract strategy implemented following Treasury yield decreases. Three-day holding period profits are consistently positive and substantial for Treasury yield decreases of three basis points or more. Average three-day holding period returns range from $18.58 \%$ (Treasury yield decrease threshold of three basis points) to $36.14 \%$ (Treasury yield decrease threshold of ten basis points). Median three-day profits are positive for all Treasury decrease thresholds except ten basis points; however, median profits decrease substantially at thresholds above seven basis points, even though average profits are increasing in this threshold range. Skewness in the profit distribution increases as the yield change threshold increases.

Profits for the municipal futures strategy persist over the five-day holding period (see Panel B). Although five-day average profits per trade are lower 


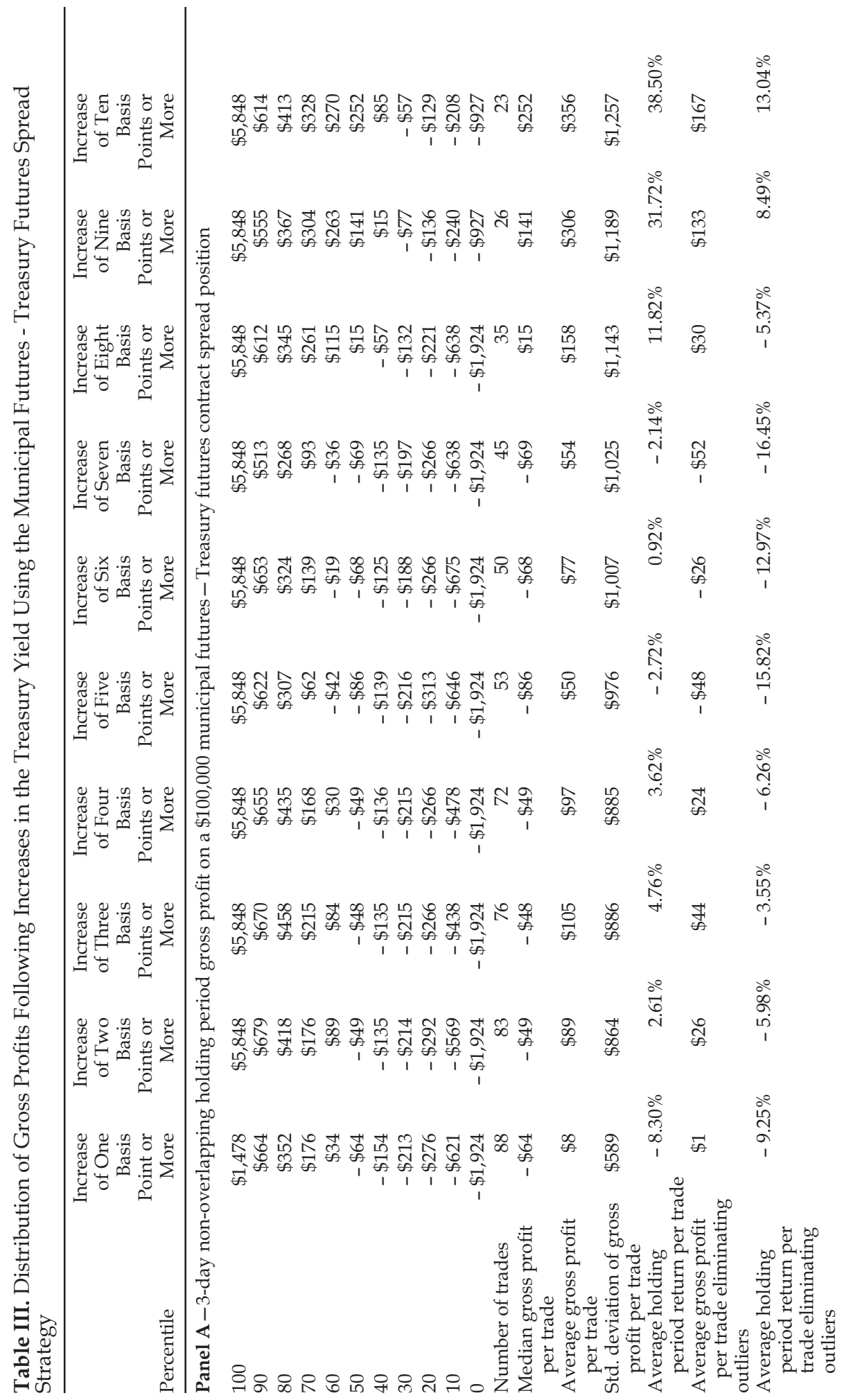




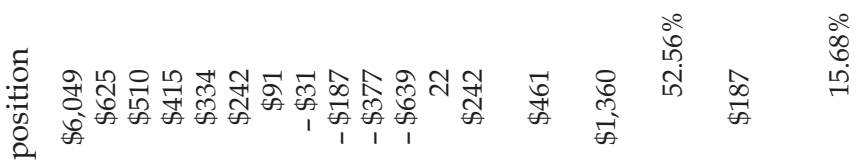

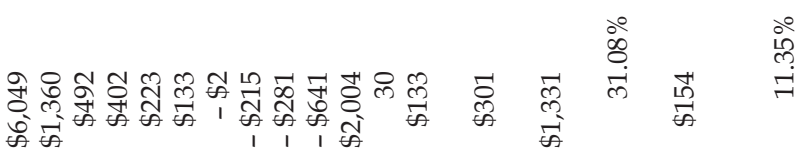

छ

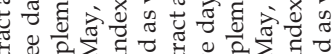

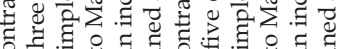

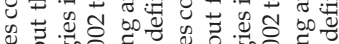

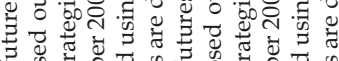

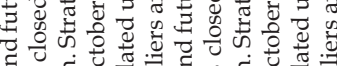

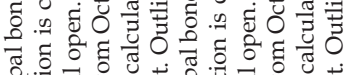

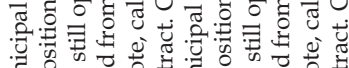

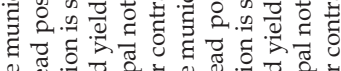

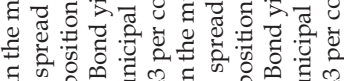

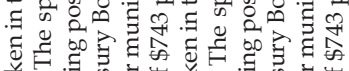

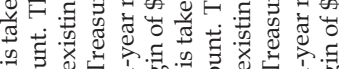

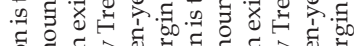

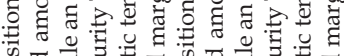

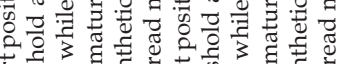

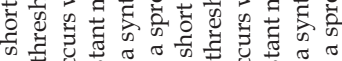

落

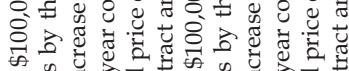

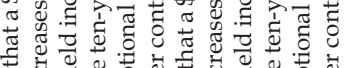

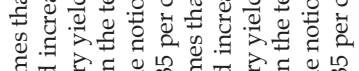

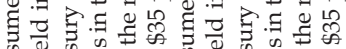

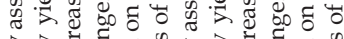

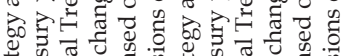

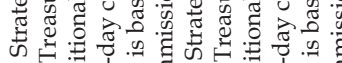

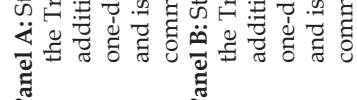




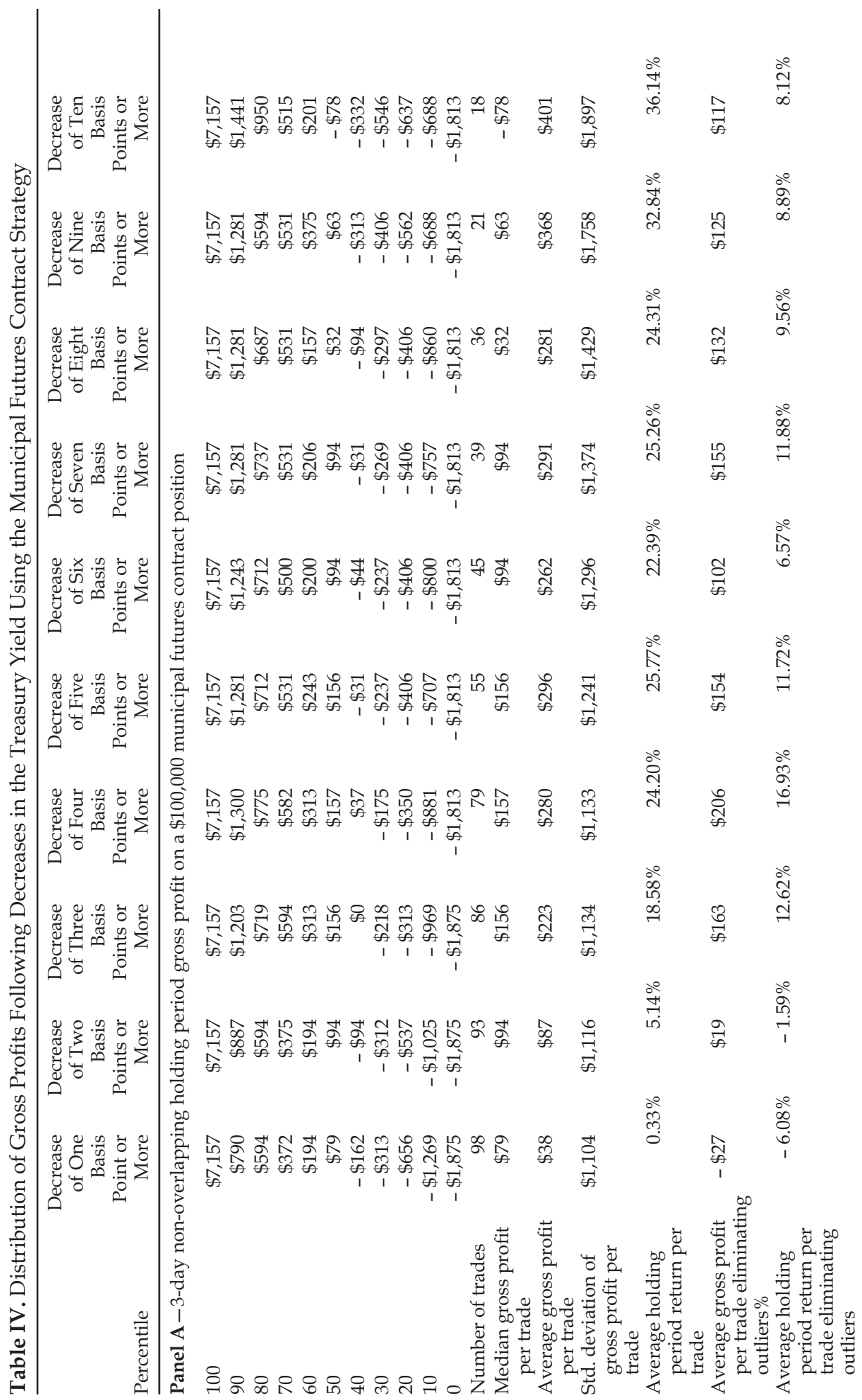




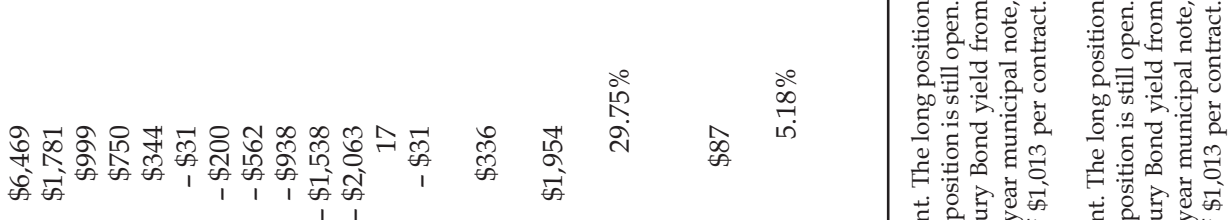

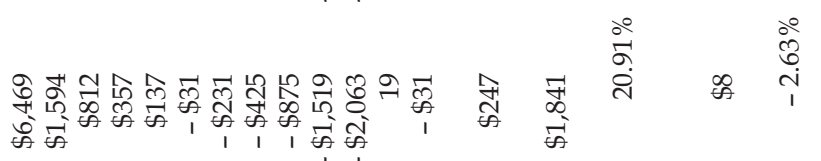

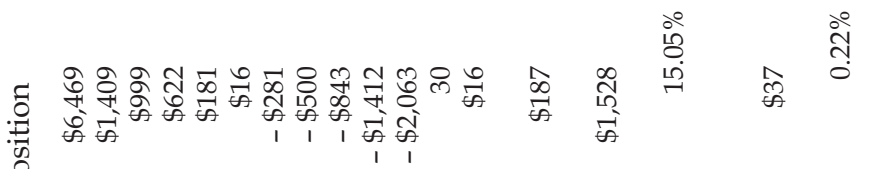

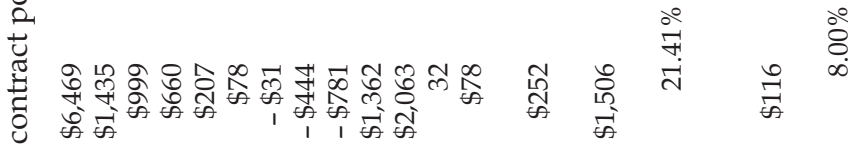

龸

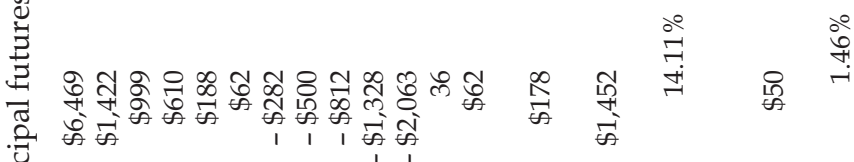

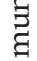

8

8

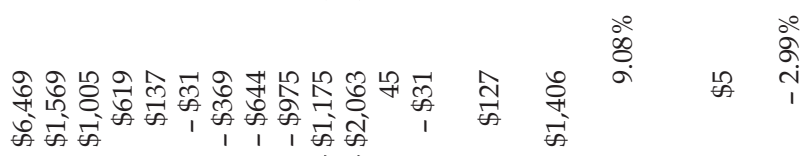

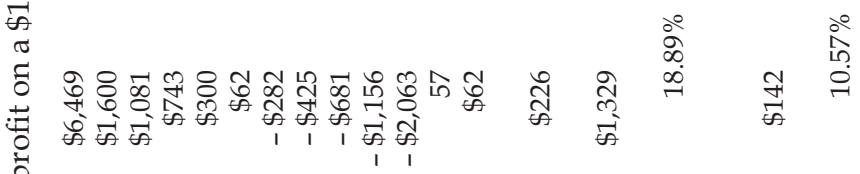

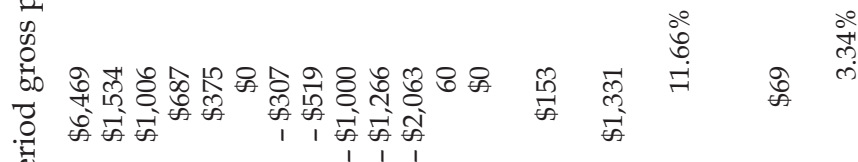

षै

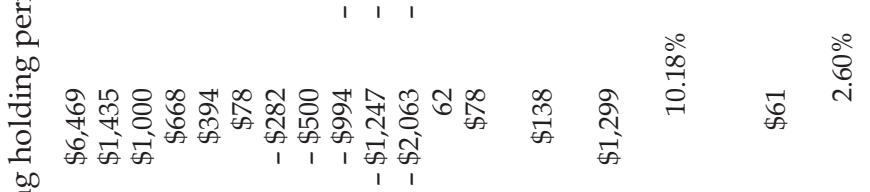

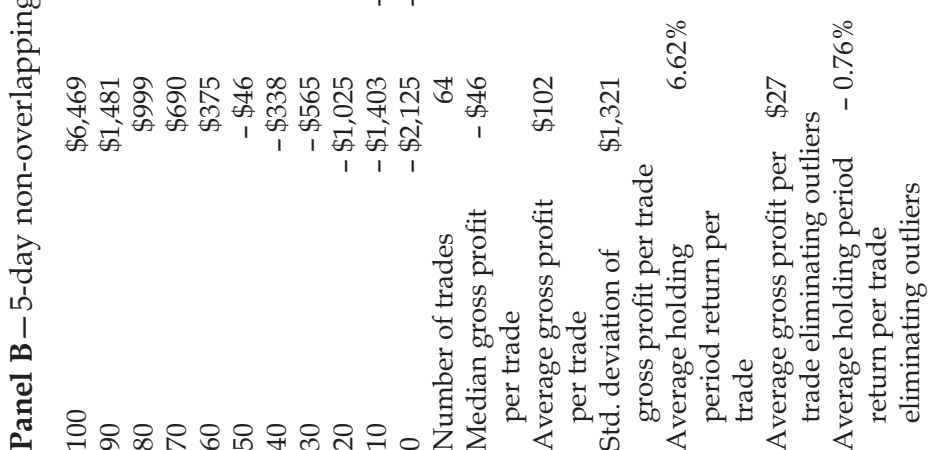

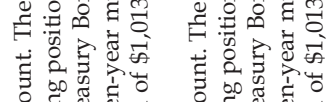

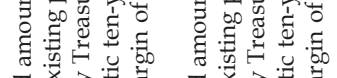

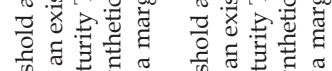

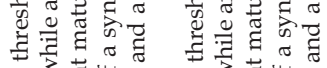

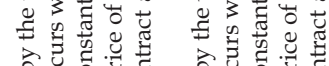

合

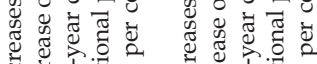

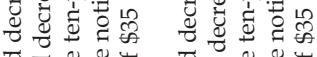

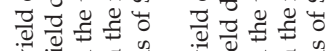

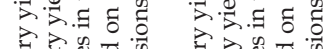

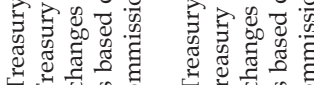

تُ

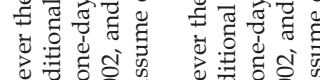

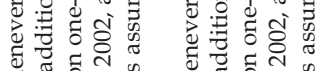

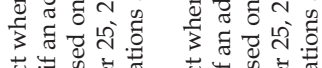

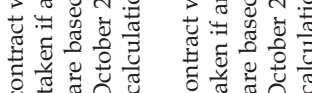

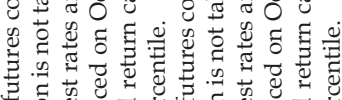

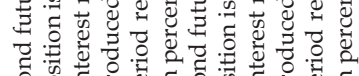

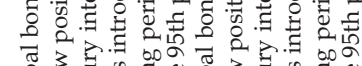

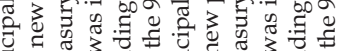

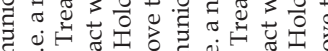

घ.

‡ ⿷匚⿱ 口)

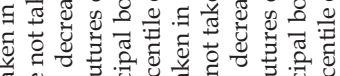

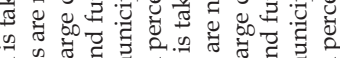

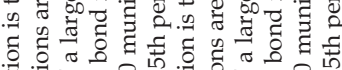

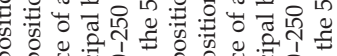

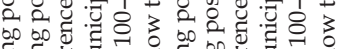

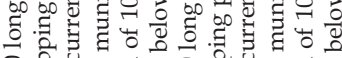

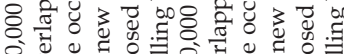

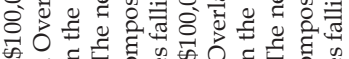

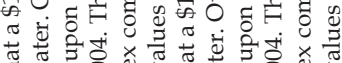

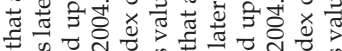

क

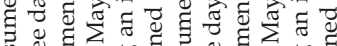

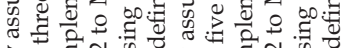

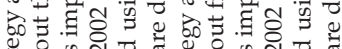

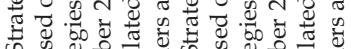


than the three-day average profits, the five-day profits remain substantial, ranging from $\$ 102$ per trade (6.62\% holding period return) for a one basis point Treasury decrease threshold to $\$ 336$ per trade $(29.75 \%$ holding period return) for a Treasury decrease threshold of ten basis points or more. Median profits remain substantially lower than average profits.

\section{Results of MOB Spread Futures Contract Strategy for Treasury Yield Decreases}

Results of the MOB spread futures contract strategy for Treasury yield decreases are given in Table V. The MOB spread futures trading strategy generally significantly underperforms the municipal futures contract trading strategy when both strategies are implemented following Treasury yield decreases. Though the municipal futures contract trading strategy generates substantial three-day per-trade trading profits for most Treasury yield decrease thresholds, the three-day average trading profits associated with the MOB spread trading strategy are consistently negative. Because the municipal contract portion of the spread strategy is profitable, the negative spread profits are due to large losses on the short position in the Treasury futures contract.

Five-day trading profits associated with the MOB spread futures trading strategy exhibit a different pattern. Average five-day profits are consistently positive, with significant profits for Treasury yield decrease thresholds of two basis points or more. The municipal futures contract strategy continues to dominate the MOB spread trading strategy for all Treasury yield decrease thresholds, but five-day returns for the MOB spread strategy are still attractive, with a holding period returns ranging from 9.71 to $22.52 \%$ for Treasury yield decrease thresholds of at least six basis points. Median five-day profits are negative for the MOB spread strategy for Treasury decrease thresholds of less than five basis points. Median gross profits are positive at thresholds of five, six, seven, eight, and nine basis points, but turn negative at ten basis points.

\section{Summary of Results}

Overall, holding period returns are more consistent across various Treasury yield change threshold levels with the municipal bond futures strategy, but the spread strategy frequently generates higher profits when implemented following large changes in Treasury yields. The municipal futures strategy generates economically significant per trade three-day holding period returns for all Treasury yield increase and decrease thresholds except the increase threshold of one-basis point. Five-day holding period returns are positive and significant for all Treasury yield decrease thresholds and for 
Treasury yield increase thresholds greater than four basis points. ${ }^{6}$ The spread trading strategy results are more variable. Although the three- and five-day holding period spread strategies are generally not profitable at smaller Treasury yield increase thresholds, the strategies are very profitable when implemented following Treasury yield increases of eight basis points or more for the three-day strategy or six basis points or more for the five-day strategy. The three-day holding period spread strategy generates consistently negative returns for all Treasury yield decrease thresholds. However, when a five-day holding period spread strategy is used, substantial positive returns are associated with Treasury yield decrease thresholds of more than five basis points.

\section{Comovements in Municipal and Treasury Yields}

Although the interaction between the municipal and Treasury prices shows complex dynamics, one can deduce several general statements about their comovements from the results of the two trading strategies. The following average behavior was noted:

(1) When there is a decrease in the spot Treasury yield, the Treasury futures price initially rises more than the municipal futures price. Between three and five days, however, the municipal futures price increase outstrips the Treasury futures price increase. The municipal futures price response is therefore more gradual, but more persistent than the Treasury response to spot Treasury yield decreases. This pattern (approximately) holds for decreases in the Treasury yield from one to ten basis points.

(2) When there is an increase in the spot Treasury yield, the municipal futures price initially falls more than the Treasury futures price independent of the magnitude of the yield increase. By five days, however, the relative price responses of the Treasury and municipal futures prices depend on the magnitude of the yield increase. The pattern suggests that for small increases in yield, the Treasury and municipal futures prices both fall, with the municipal price initially falling faster but the Treasury price catching up within five days. For large yield increases, the Treasury responses diverge (initially falling and then rising), making the spread strategy particularly profitable.

6. Table I gives the numbers of Treasury yield changes of varying magnitudes during the sample period. It should be noted that the breadth of the strategies is limited by the frequency of large changes in the Treasury yields. In general, the number of profitable trades depends on the magnitude of the Treasury yield change. As an indication of the availability of trades (aggregating over all threshold levels), the Treasury yield decreased 221 times. The municipal futures contract strategies resulted in 98 trades of which 49 were profitable trades. However, due to the high skewness in the profit distribution, the dollar profits significantly outweigh the dollar losses. Similar trading frequency and profitability apply following Treasury yield increases. 
क

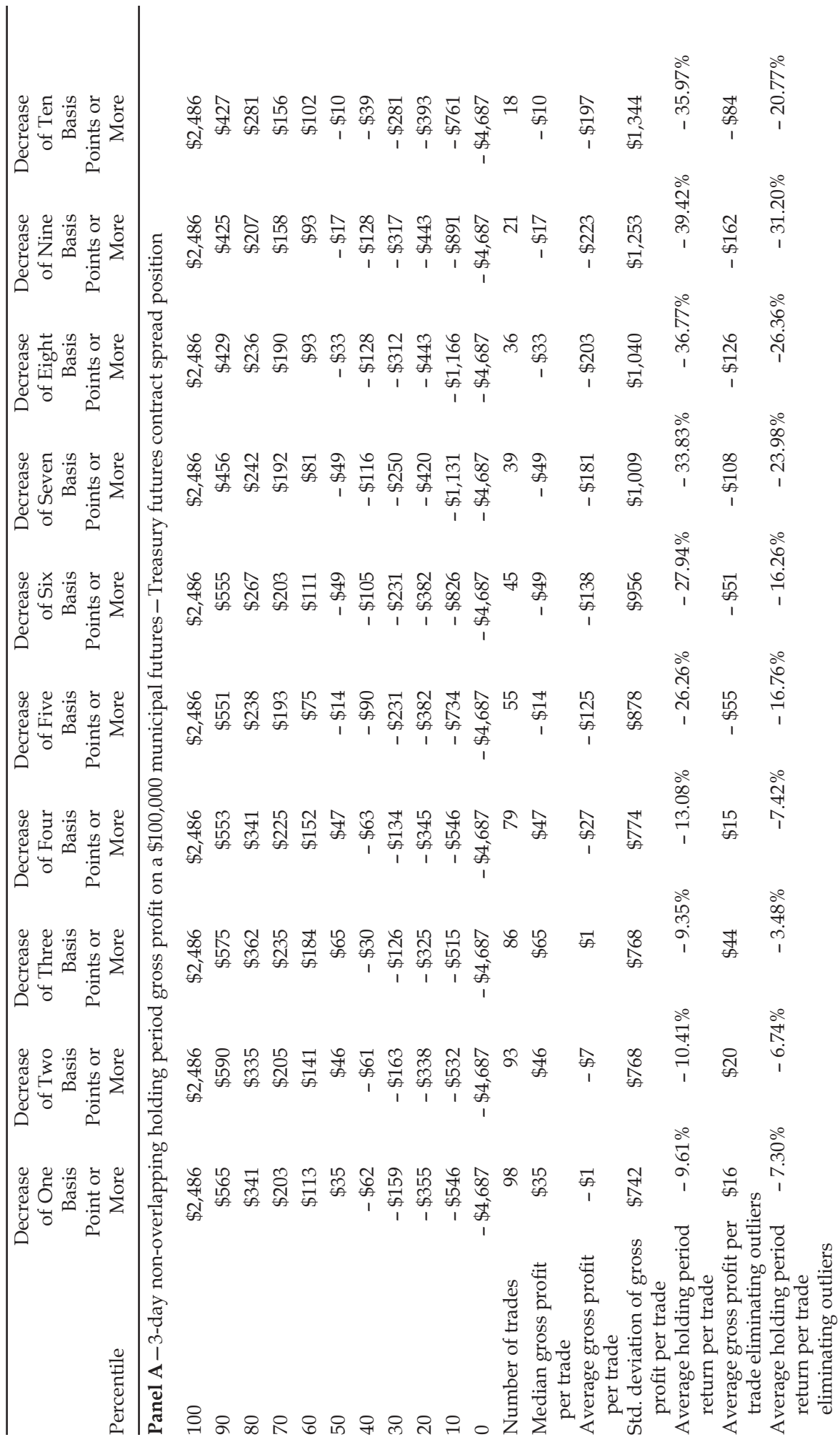




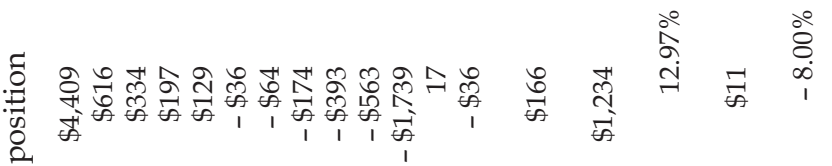

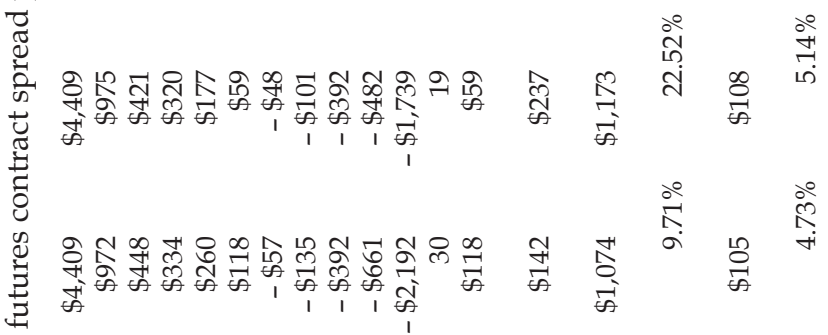

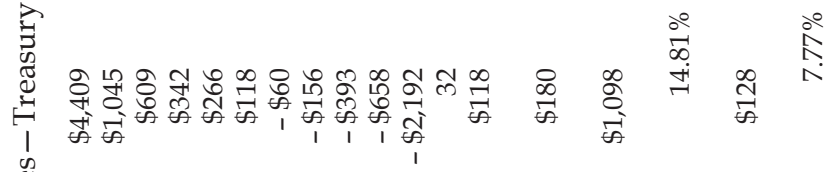

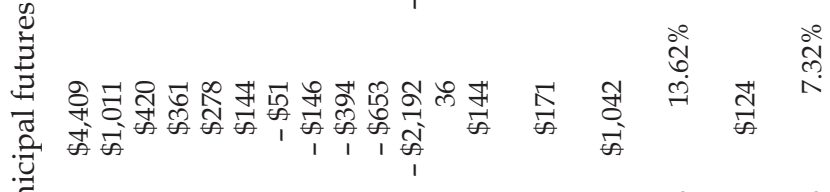

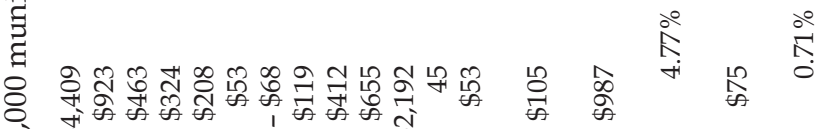

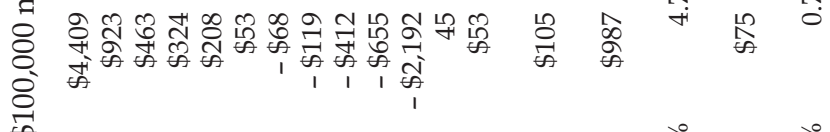

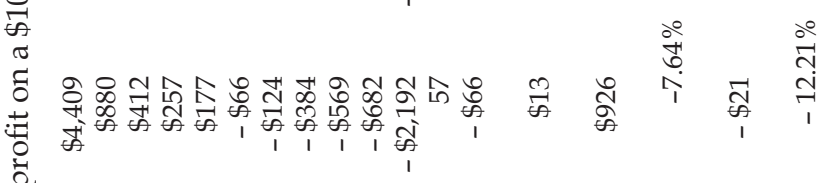

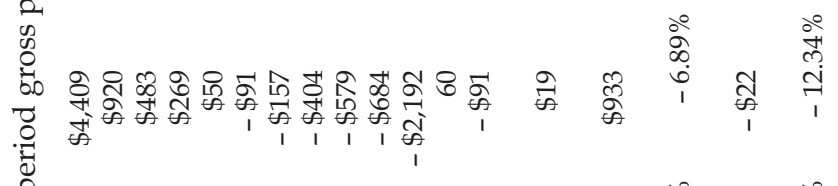

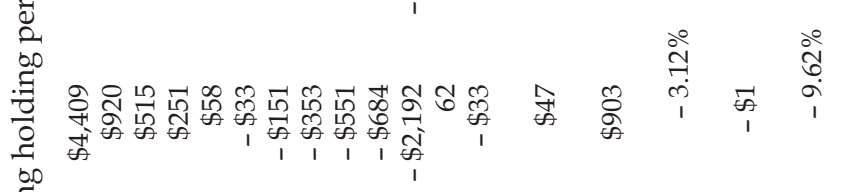

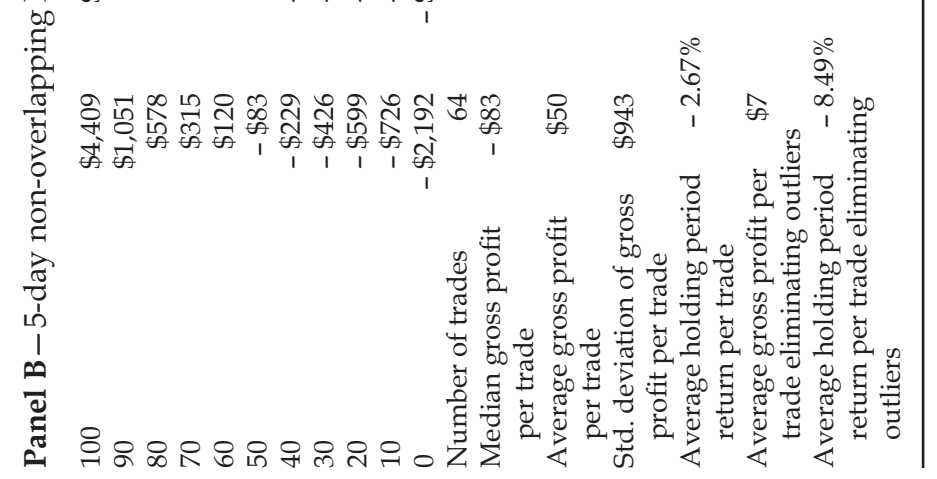

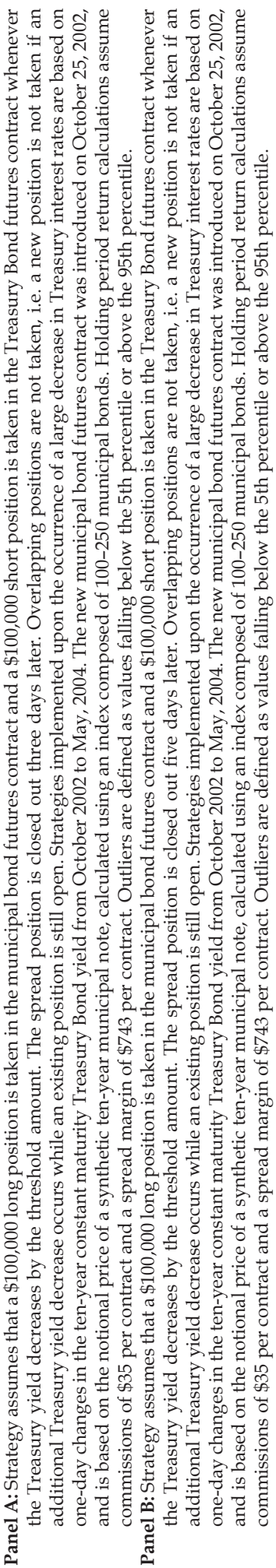




\section{Robustness Test Results}

The profit distributions for most Treasury yield increase or decrease thresholds are skewed. As a result, it is possible that the average profits from both strategies are due to a few large outliers. To test whether the results are driven by outlier observations, the average profits from both strategies were recalculated after first eliminating observations above the 95th percentile and below the fifth percentile of each distribution. Return calculations excluding outliers are shown on the last two rows of each of the results tables (Tables II-V). Although returns are smaller, the municipal futures contract strategy continues to be profitable for Treasury yield change thresholds of five basis points or more (except for the ten basis point threeday Treasury yield increase threshold). For yield increases, the five-day returns on the municipal futures contract remain higher than the three-day returns. Five-day returns on the spread futures strategy are also higher than three-day returns when this strategy is implemented following Treasury yield increases. Spread strategy returns are positive and economically significant for Treasury yield change thresholds of six basis points or more for the five-day holding period; for the three-day holding period, average returns are positive only for Treasury yield change thresholds of nine and ten basis points. In the complete untrimmed data yield increase results, the spread futures strategy outperformed the municipal futures strategy for the five-day holding period. When outliers are removed, the municipal futures strategy dominates the spread futures strategy for yield change thresholds of seven, eight, and nine basis points.

For yield decreases, average returns for the three-day municipal futures contract strategy remain positive and economically significant for Treasury yield decrease thresholds of three basis points and higher. However, only the seven and ten basis point decrease thresholds remain economically significant for the five-day holding period. While the average returns to the three-day holding period spread strategy improve after outliers are removed, the returns remain negative for all yield decrease thresholds. The five-day holding period spread strategy average returns are positive and economically significant for yield decrease thresholds of six, seven, eight, and nine basis points.

Although these trading strategies generate substantial average profits, the volatility of the trading profits may make the strategies unattractive to professional arbitragers. As shown in Tables II-V, the strategies have sizable standard deviations relative to their mean profits. In addition, the profits generated by the trading strategies are skewed, which can result in a frequent number of losses. For example, over all the thresholds in the Treasury yield increases (Table II, for the three day and five day holding periods), there were 972 trades. Of these 972 trades, $47 \%$ resulted in profitable trades. 
However, because of the skewness, the dollar profit from these trades outweighs the smaller (though more numerous) dollar value of the trading losses. The strategy would generate substantial profits over time, but the investor would have to have sufficient funds and risk tolerance to ride out the losses.

As noted by Shleifer and Vishny (1997), professional arbitrage carried out by a relatively small number of specialized investors using other people's capital may become ineffective if those providing the capital do not understand exactly what the money manager is doing. Even if a position is ultimately profitable, if it generates variable outcomes (and potentially results in margin calls), investors may attribute the variability to money manager incompetence and refuse to provide him with more capital. Fearing this, the manager may avoid positions with highly variable outcomes, even if the position is profitable on average. This allows profit opportunities to persist instead of being eliminated by arbitrage activity. Schleifer and Vishney's analysis may be applicable to the trading strategies examined in this paper.

\section{Conclusions}

This study examines the profitability of two futures strategies designed to exploit a slow adjustment in municipal yields following a change in taxable yields. Under the first strategy, investors take a short (long) position in the municipal bond futures contract following large increases (decreases) in the Treasury yield. In the second strategy, following a large increase (decrease) in the Treasury yield, investors take a short (long) position in the MOB spread. The returns associated with three- and five-day holding periods for each futures trading strategy are examined following treasury yield changes of from one to ten basis points.

Both strategies consistently generate attractive average returns when implemented for five-day holding periods after Treasury yield increases or decreases of six basis points or more. For example, five-day holding period returns for the municipal bond futures trading strategy range from 7.98 to $19.76 \%$ following Treasury yield increases and from 14.11 to $29.75 \%$ following Treasury yield decreases of six basis points or more. Trading strategy holding period returns tend to increase with the magnitude of changes in the Treasury yield. The municipal futures trading strategy outperforms the spread strategy for small Treasury yield changes, but the spread strategy frequently generates superior returns for large Treasury yield changes.

The profitability of the futures trading strategies is consistent with a slow adjustment in municipal yields following changes in Treasury yields. Based upon the results of both strategies, the municipal futures price response fol- 
lowing a decrease in the spot Treasury yield is on average more gradual but more persistent than the Treasury futures price response. Following small increases in spot Treasury yields, the Treasury and municipal futures prices both fall. The municipal price tends to initially fall faster, but the Treasury price catches up within five days. Following large spot Treasury yield increases, the Treasury futures price response tends to reverse (initially falling and then rising), making the spread strategy particularly profitable.

Substantial profit opportunities from simple futures trading strategies are documented. However, the profit distributions for both futures strategies are positively skewed and the strategies frequently generate negative profits for individual events. Despite the attractive average profits generated by both strategies, the volatility associated with the profit distributions may make these strategies less attractive to professional money managers.

\section{Bibliography}

Ang, J. D., Peterson, D., \& Peterson, P. (1985). Marginal tax rates: evidence from nontaxable corporate bonds: A note. Journal of Finance, 40, 327-332.

Arak, M., Fischer, P., Goodman, L., \& Daryanani, R. (1987). The municipal-treasury futures spread. Journal of Futures Markets, 7, 355-371.

Buser, S. A., \& Hess, P. J. (1986). Empirical determinants of the relative yields on tax able and tax-exempt securities. Journal of Financial Economics 17, 335-355.

CBOT Celebrates 25th Anniversary of its Interest Rate Complex. Chicago Board of Trade, http://www.cbot.com/cbot/pub/cont_detail/0,3206,1036 8491,00. $\underline{\mathrm{html}}$.

CBOT 10-Year Muni Note Index Futures Reference Guide. Chicago Board of Trade, http://www.cbot.com/cbot/docs/36766.pdf.

Chalmers, J. (2006). Systematic risk and the muni puzzle. National Tax Journal, 59, 754-754.

Corrado, C. J., \& Zivney, T. L. (1992). The specification and power of the sign test in event study hypothesis tests using daily stock returns. Journal of Financial and Quantitative Analysis, 27, 465-478.

Creating a Viable Contract: Issues and Recommendations Relating to the Municipal Bond Futures Contract. Bond Market Association Municipal Futures Task Force, May 2000.

Downing, C., \& Zhang, F. (2004). Trading activity and price volatility in the municipal bond market. Journal of Finance, 59, 899-931.

Erickson, M., Goolsbee, A., \& Maydew, E. (2003). How prevalent is tax arbitrage? Evidence from the market for municipal bonds. National Tax Journal, 56, 259-270. 
Green, R. C. (1993). A simple-model of the taxable and tax-exempt yield curves. Review of Financial Studies, 6, 233-264.

Hamilton, T. R., Hein, S. E., \& Koch, T. W. (1994). The pricing of municipal bond index futures. Journal of Futures Markets, 14, 575-596.

Harris, L. E., \& Piwowar, M. S. (2006). Secondary trading costs in the municipal bond market. Journal of Finance, 61(3), 1361-1397.

Heaton, H. (1988). On the possible tax-driven arbitrage opportunities in the new municipal bond futures contract. Journal of Futures Markets, 8, 291-302.

Hung, M. W., \& Zhang, H. (1995). Price movements and price discovery in the municipal bond index and the index futures markets. Journal of Futures Markets, 15, 489-506.

Kryzanowski, L., Xu, K., \& Zhang, H. (1995). Determinants of the decreasing term structure of relative yield spreads for taxable and tax-exempt bonds. Applied Economics, 27, 583-590.

Litzenberger, R. \& Rolfo, J. (1984). Arbitrage pricing, transactions costs and taxation of capital gains: A study of government bonds with the same maturity date. Journal of Financial Economics, 13, 337-351.

McCue, M., \& Stevens, J. (1992). Market segmentation and the residual demand for tax-exempt and taxable bonds. Journal of Business Finance and Accounting, 19, 777-788.

Shleifer, A., \& Vishny, R. W. (1997). The limits of arbitrage. Journal of Finance, 52, 35-55.

Skelton, J. (1983). Banks, firms and the relative pricing of tax-exempt and taxable bonds. Journal of Financial Economics, 12, 343-355.

Stoll, H. R., \& Whaley, R. E. (1990). The dynamics of stock index and stock index futures returns. Journal of Financial and Quantitative Analysis, 25, 441-468.

Wu, C., Wang, J., \& Zhang, F. (2006). Liquidity, default, taxes and yields on municipal bonds. FEDS Working Paper No. 2005-35. Available at SSRN: http:// $\underline{\text { ssrn.com/abstract }=687500}$ 